\title{
The Well Control Equipment of Tarim Oil Field Surpressure Gas Well
}

\author{
Kaihong Zhou a, Hongji Fang, Bo Fan \\ Guilin University of Technology, China \\ ayeyeyuyu2@qq.com
}

Keywords: Tarim, ultra-high pressure, gas well, well control equipment.

\begin{abstract}
Before 2004, the temporal pressure control technique and the well control equipment could not completely meet the requirement of exploration and development in the Tarim oil field surpressure gas reservoir (more than $70 \mathrm{MPa}$ ). Through setting and analyzing of more than 10-year site investigation, theoretical analysis and experimental research, on the basis of summing up the experience of Tarim oil field, to seek solutions to reliable technology and method of well control equipment used in the surpressure gas well, for preferable exploration and development in the Tarim oil field surpressure gas well.
\end{abstract}

\section{Introduction}

The Tarim piedmont tectonic belt of ultra-high pressure oil gas drilling ${ }^{[1-3]}$, drilling fluid density and adding iron ore powder, used in the 2004 before the pressure control technology and well control equipment cannot fully meet the needs of exploration and development wells. Ultra-high pressure high production wells, through the existing system will throttle pressure below $1 \mathrm{MPa}$ will enter the cyclone closed throttle system is very small, in the ultra-high pressure, high yield under complex conditions, it is prone to clogging, stab, breaking failure, even if we replace it with imported equipment, also useless. In recent 10 years through field investigation of failure mode, theoretical analysis and experimental study, based on summarizing the practice experience of many years in Tarim Oilfield, seeking to solve well control equipment use technology and reliable method in ultra-high pressure gas well under complex conditions, formulate feasible, scientific and practical use of management practices to meet the needs of the piedmont tectonic belt ultra-high pressure gas exploration and development has made significant progress;FKQ1400/0.862 (FKG1200/0.862) separator was also reformed. Also the restructuring of a single flow valve structure, solves the problem of high density drilling fluid erosion, gas separation effect is poor and some weak points such as well control equipment has made significant progress, to avoid the emergence of well control equipment failure process technology to implement well control, ensure the continuity of well control technology implementation. At present, the well control equipment and technology of the ultra-high pressure gas well have been matched to form a set of well control technology ${ }^{[5,6]}$,it can be used to guide the control of the high pressure gas wells in the future, and to make up for the shortage of the well control work ${ }^{[5-8]}$. Ultra high pressure gas well control equipment, the combination of three types: Combination type I mainly used for pressure level 70MPa (Table 1);Combination type II is mainly Used for pressure level 105MPa (Table 2); Combined supporting type III is mainly used for abnormal Table 1 Specification for the combination type of wellhead equipment and well control equipment for ultra-high pressure gas wells

High pressure and abnormal area exploration of 105MPa.The well control equipment of the ultra-high pressure gas well is mainly composed of the following parts:

1). Multistage throttle manifold;

2). Ultra high pressure gas well gas separator;

3). Reverse circulation kill line;

4). Drilling fluid pneumatic weighting system. 
Table 1 Specification for the combination type of wellhead equipment and well control equipment for ultra high pressure gas wells

\begin{tabular}{|c|c|c|c|c|c|}
\hline \multirow{3}{*}{$\begin{array}{l}\text { Task type } \\
\text { Casing } \\
\text { size mm } \\
\text { (in) }\end{array}$} & \multicolumn{3}{|c|}{ Drilling } & \multirow{2}{*}{\multicolumn{2}{|c|}{$\begin{array}{l}\text { Oil testing and workover } \\
\text { Fifth time drilling }\end{array}$}} \\
\hline & \multirow{2}{*}{$\begin{array}{c}\begin{array}{c}\text { Second } \\
\text { time } \\
\text { drilling }\end{array} \\
508.0(20)\end{array}$} & \multirow{2}{*}{$\begin{array}{c}\begin{array}{c}\text { Third time } \\
\text { drilling }\end{array} \\
339.7(13-3 / 8)\end{array}$} & \multirow{2}{*}{$\begin{array}{c}\begin{array}{c}\text { Fourth time } \\
\text { drilling1) }\end{array} \\
244.5(9-5 / 8) 1)\end{array}$} & & \\
\hline & & & & 177.8(7)2) & 177.8(7) \\
\hline $\begin{array}{c}\text { Type of } \\
\text { wellhead } \\
\text { assembly }\end{array}$ & $\begin{array}{l}508.0(20) \\
\text { Casing } \\
\text { head } \\
54-14 \text { The } \\
\text { high and } \\
\text { low } \\
\text { stopcock } \\
\text { FPS54-14 } \\
\text { Drilling } \\
\text { spool } \\
\text { FZ54-14 } \\
\text { Single ram } \\
\text { type BOP } \\
\text { FH54-14 } \\
\text { Annular } \\
\text { preventer }\end{array}$ & $\begin{array}{c}\text { 508.0(20) Casing } \\
\text { head } \\
\text { 339.7(13-3/8) Casing } \\
\text { pipe } \\
\text { 35-70 The high and } \\
\text { low stopcock } \\
\text { FPS35-70 Drilling } \\
\text { spool } \\
\text { 2FZ35-70 } \\
\text { Single ram type BOP } \\
\text { FZ35-70 } \\
\text { Single ram type BOP } \\
\text { FH35-35/70 Annular } \\
\text { preventer }\end{array}$ & $\begin{array}{c}\text { 508.0(20) Casing } \\
\text { head } \\
\text { 339.7(13-3/8) } \\
\text { Casing pipe } \\
\text { 244.5(9-5/9)Casing } \\
\text { pipe } \\
\text { FPS28-105 } \\
\text { Drilling spool } \\
\text { 2FZ28-105 Double } \\
\text { ram type } \\
\text { FZ28-105 } \\
\text { Single ram type } \\
\text { BOP } \\
\text { FH28-70/105 } \\
\text { Annular preventer }\end{array}$ & $\begin{array}{c}\text { 508.0(20) Casing } \\
\text { head } \\
\text { 339.7(13-3/8) } \\
\text { Casing pipe } \\
\text { 244.5(9-5/9)Casing } \\
\text { pipe } \\
\text { 177.8(7) Casing } \\
\text { head } \\
\text { 18/28-105 Adapter } \\
\text { flange } \\
\text { 2FZ28-105 Double } \\
\text { ram type } \\
\text { FZ28-105 } \\
\text { Single ram type } \\
\text { BOP } \\
\text { FH28-70/105 } \\
\text { Annular preventer }\end{array}$ & $\begin{array}{c}\text { 508.0(20) Casing } \\
\text { head } \\
\text { 339.7(13-3/8) } \\
\text { Casing pipe } \\
\text { 244.5(9-5/9)Casing } \\
\text { pipe } \\
\text { 177.8(7) Casing } \\
\text { head } \\
\text { 18/23-70 Reducing } \\
\text { cross } \\
\text { 2FZ28-105 Double } \\
\text { ram type } \\
\text { FZ28-105 } \\
\text { Single ram type } \\
\text { BOP } \\
\text { FH28-70/105 } \\
\text { Annular preventer }\end{array}$ \\
\hline $\begin{array}{l}\text { Type of } \\
\text { well } \\
\text { control }\end{array}$ & & & 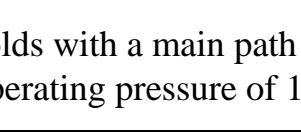 & less tl & $3-1 / 1$ \\
\hline
\end{tabular}

Table 2 standard for the combination of wellhead equipment and well control equipment of ultra high pressure gas well - II

\begin{tabular}{|c|c|c|c|c|c|}
\hline \multirow{3}{*}{$\begin{array}{c}\text { Task } \\
\text { type }\end{array}$} & \multicolumn{3}{|c|}{ Drilling } & \multirow{2}{*}{\multicolumn{2}{|c|}{$\begin{array}{l}\text { Oil testing and workover } \\
\text { Fifth time drilling }\end{array}$}} \\
\hline & \multirow{2}{*}{$\begin{array}{c}\begin{array}{c}\text { Second time } \\
\text { drilling }\end{array} \\
508.0(20)\end{array}$} & \multirow{2}{*}{$\begin{array}{c}\begin{array}{c}\text { Third time } \\
\text { drilling }\end{array} \\
339.7(13-3 / 8)\end{array}$} & \multirow{2}{*}{$\begin{array}{c}\begin{array}{c}\text { Fourth time } \\
\text { drilling }{ }^{1)}\end{array} \\
244.5(9-5 / 8)\end{array}$} & & \\
\hline & & & & $177.8(7)^{2)}$ & $177.8(7)$ \\
\hline $\begin{array}{l}\text { Type of } \\
\text { wellhead } \\
\text { assembly }\end{array}$ & $\begin{array}{c}\text { 508.0(20) } \\
\text { Casing head } \\
\text { 54-14 The high } \\
\text { and low } \\
\text { stopcock } \\
\text { FPS54-14 } \\
\text { Drilling spool } \\
\text { FZ54-14 Single } \\
\text { ram type BOP } \\
\text { FH54-14annular } \\
\text { preventer }\end{array}$ & $\begin{array}{c}\text { 508.0(20) Casing } \\
\text { head } \\
\text { 339.7(13-3/8) } \\
\text { Casing pipe } \\
\text { 35-35The high and } \\
\text { low stopcock } \\
\text { 35-35/70 } \\
\text { Transformer flange } \\
\text { FPS35-70 Drilling } \\
\text { spool } \\
\text { 2FZ35-70 Double } \\
\text { ram type } \\
\text { BOPFZ35-70 } \\
\text { Single ram type } \\
\text { BOP } \\
\text { FH35-35/70annular } \\
\text { preventer }\end{array}$ & $\begin{array}{c}\text { 508.0(20) Casing } \\
\text { head } \\
\text { 339.7(13-3/8)casing } \\
\text { pipe } \\
\text { 244.5(9-5/8)Casing } \\
\text { pipe } \\
\text { 35/28-70 } \\
\text { Transformer flange } \\
\text { FPS35-70 Drilling } \\
\text { spool } \\
\text { 2FZ35-70 Double } \\
\text { ram type } \\
\text { BOPFZ35-70 Single } \\
\text { ram type BOP } \\
\text { FH35-35/70annular } \\
\text { preventer }\end{array}$ & $\begin{array}{c}\text { 508.0(20) Casing } \\
\text { head } \\
\text { 339.7(13 -3/8) } \\
\text { Casing pipe } \\
\text { 244.5(9-5/8)Casing } \\
\text { pipe } \\
\text { 177.8(7) Tubing } \\
\text { head } \\
\text { 18/35-70 Adapter } \\
\left.\text { flange }{ }^{3}\right) \\
\text { 2FZ35-70 Double } \\
\text { ram type } \\
\text { BOPFZ35-70 } \\
\text { Single ram type } \\
\text { BOP } \\
\text { FH35-35/70annular } \\
\text { preventer }\end{array}$ & $\begin{array}{c}\text { 508.0(20) Casing } \\
\text { head } \\
\text { 339.7(13 -3/8) } \\
\text { Casing pipe } \\
\text { 244.5(9-5/8) Casing } \\
\text { pipe } \\
\text { 177.8(7) Tubing } \\
\text { head } \\
\text { 18/23-70 Adapter } \\
\text { Spool }{ }^{4)} \\
\text { 2FZ23-70 Double } \\
\text { ram type } \\
\text { BOPFZ23-70 } \\
\text { Single ram type } \\
\text { BOP } \\
\text { FH23-35/70annular } \\
\text { preventer }\end{array}$ \\
\hline $\begin{array}{l}\text { Type of } \\
\text { well } \\
\text { control }\end{array}$ & & & piessuie or torvi & $77.8 \mathrm{~m}$ & 6in) ratec \\
\hline
\end{tabular}




\section{Preventer}

The annular blowout preventer(as shown in fig.1) of the ultra-high pressure gas well is made up of FH35-35/70 annular blowout preventer and FH28-70/105 annular blowout preventer, and ball core structure. Ultra-high pressure gas well gate ram blowout preventer uses FZ35-70 single / double ram blowout preventer and FZ28-105 single / double ram blowout preventer, such as the shell of forging parts, gate rubber core using long-life structure, side seal ring with radial floating ring, the locking mechanism adopts hydraulic lock, can be used to cut the high shear ram impact energy of S135 drill pipe blowout preventer for ultra-high pressure gas well before the ram preventer seal test, regular preventer on the use of more than 10 years to prevent the residual stress and acoustic emission testing, and to detect the main seal parts, in case of failure.

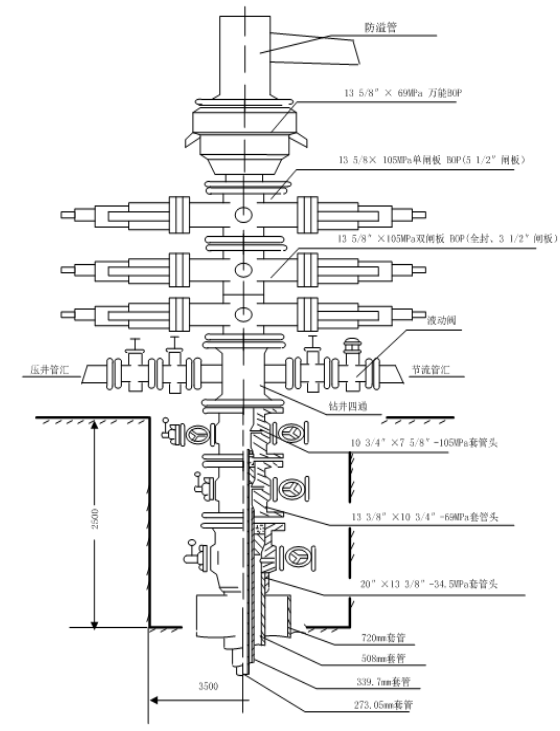

Fig.1 Schematic diagram of High pressure gas wellhead

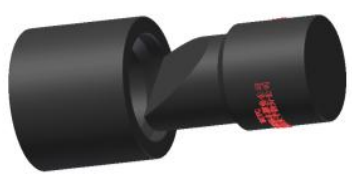

Fig. 2 Wedge throttle body

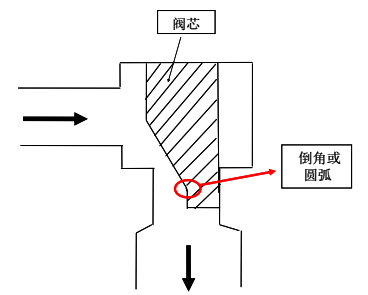

Fig.3 Wedge valve structure

\section{Multistage throttle manifold}

Standard nozzles and choke manifold systems with rated operating pressure of $70 \mathrm{MPa}$ or $105 \mathrm{MPa}$ for ultra-high pressure gas wells. The multi stage throttle system is used to replace the single stage throttle system in the ultra-high pressure gas well. The throttling manifold configuration of $105 \mathrm{MPa}$ can be used to implement the three stage of pressure control manifold; the throttling manifold configuration of $70 \mathrm{MPa}$ can be used to implement the two stage of pressure control manifold. Pressure gauges and sensors are arranged on the upstream and downstream of each throttle valve. The two stage or the three stage throttle valve is used to share the high pressure drop, and the service life of the throttle valve is improved. A pressure sensor and a pressure gauge are arranged on the upstream and downstream of the throttle valve to judge the working condition of the throttle valve.

\subsection{Wedge throttle valve}

Throttle valve is the key equipment to control the wellhead pressure, to control and maintain the stability of under pressure in underbalanced drilling. Good linear characteristics, relative economic manufacturing costs, long-term stability of the field application is the focus of the development and 
application of throttle valve. Wedge throttle valve overcomes the shortcomings of the throttle valve spool easy to fall off and lose the role of a good linearity, good erosion resistance, shown in Fig.2.

For the two section of the plane of the wedge valve, the junction of the two plane should be chamfered or arc, in order to reduce the parallel to the axis of the plane of the erosion of the plane, shown in Fig.3.Through the research and application of the throttle valve, it makes a great leap in the well control equipment in Tarim area.

\subsection{Kill manifold}

At the same time, a single flow valve is installed on both ends of the pressure relief pipe of the ultra-high pressure gas well, and it can meet the need of the reverse circulation well killing of the mud pump and the fracturing vehicle. At the same time, the two ends of the well pressure manifold of the ultra-high pressure gas well are equipped with a single flow valve, which can meet the need of the reverse circulation well killing of the mud pump and the fracturing vehicle.

\section{Mud gas separator}

The NQF800/0.7 at the scene to deal with the small quantity and high failure rate, cannot meet the needs of production, the Tarim oilfield through investigating the mud gas separator structure, combined with the actual situation of the Tarim, after repeated discussions of technical staff, has developed NQF1400/0.862 type and NQF1200/0.862 type mud gas separator; the diameters of the two large separator tanks are $1.2 \mathrm{~m}$ and $1.4 \mathrm{~m}$, the quantity of separations can reach more than $600000 \mathrm{~m}^{3}$, used successively in preliminary prospecting wells, high pressure and ultra-high pressure wells, underbalanced drillings and drillings with H2S(Table 3).From the use of the situation, they have a significant separation effect, high security. There is no failure at the scene, and they meet the needs of production.

\section{Throttle kill line of reverse circulation}

Ultra-high pressure gas wells in Tarim Oilfield, the process of drilling wells, do not know when the formation conditions, due to design and well mud density leakage and overflow occurred during the drilling process is often the case. In handling this kind of high pressure gas overflow occurs during positive circulation pressure well conventional methods of gas at the same time will bring more areas to the wellhead, may cause high wellhead pressure, while supporting the well control equipment rated working pressure is usually $70 \mathrm{MPa}$, a few $105 \mathrm{MPa}$.This poses a serious threat to the wellhead pressure well blowout preventer and in kill operation for safety control throttle manifold and other well control equipment, command of relevant technical personnel wells will cause great psychological pressure, Especial in a long drilling process, the inner wall of the casing of oil and gas technology resulting in the upper part of the serious wear, causing the bearing capacity gets greatly reduced, in this case, it cannot afford the high wellhead pressure. Therefore, it is not appropriate to use the normal circulation well killing method for the overflow treatment of some high pressure gas wells.

Reverse circulation throttling well killing technology is used in the well killing process of well $\mathrm{Wu}-1$.In the process of actual well killing, the casing pressure is not higher than 25MPa.It creates favorable conditions for the implementation of the well killing. It is proved that the process and pressure control of the reverse circulation choke well are effective.

\section{Drilling fluid pneumatic pressurization system}

Gas pressure is used as power source in drilling fluid pneumatic pressure system, the powder material in the ash storage tank is fluidized by using the compressed gas and the fluidization device, and the material is gradually suspended; When the ash is passed, the ash conveying valve is opened, and the air pressure difference between the inside and the outside of the tank is utilized to drive the suspended material to output the ash storage tank to realize the pneumatic ash adding. The system consists of four parts: gas path, ash road, and control metering and dust removal. The process 
principle is:The bulk material is transported to the well site and stored in the ash storage tank by the pneumatic ash conveying vehicle, the material is output to the mixing device through the pneumatic slurry mixing device and is mixed with the mud.

\section{Conclusion}

Tarim Oilfield super high-pressure gas well control equipment is mainly summed up in 2003 before the Tarim oil field well control experience and lessons, especially the well Dina 2 on the basis of experience and lessons, through more than 10 years of continuous research and innovation, now has become mature; the popularization and application of wedge throttle valve, multistage throttle system, drilling fluid pneumatic pressurization system, reverse circulation drilling technology and high density mud degassing technology. Practice has proved that the super high pressure gas well control equipment has been basically solved the problem of ultra-high pressure gas well control safety, provide powerful technical support for the ultrahigh pressure gas well drilling.

\section{References}

[1] Robert D Grace Blowout and well control manual [M].Beijing: Petroleum Industry Press, 2001

[2] Li Feng, Yu Xianyou et al. Exploration and practice of well control safety technology and Management mode in exploratory wells in Tarim Oilfield [J]. Drilling \&amp; Production Technology, 2006, 29(5):111 113.

[3] Zhu Jin Fu, Chen Yuzhong et al.High pressure oil and gas well head control Configuration [J].Oil and gas well test, 2008, 17(4):72 74

[4] Du Xiaorui, Wang Guiwen et al. Handbook of drilling tools [M].Beijing: Petroleum Indu stry Press, 1991, 12

[5] Jonggeun Chechens C.Juvkam-wold. Modified Two-Phase Well-Control Model and Its Computer Applications as a Training and Educational Toolset 37688, 1997

[6] O.L.A.Snntos. Well control operations in Horizontal wells. SPE 21105, 1991

[7] BA,rre Fossli.Controlled Mud-Cap Drilling for Subsea Applications: Well-Control Challenges in Deep Waters.SPE 91633, 2006

[8] E. N. Monterio and P. R. Ribeiro, Unicamp. Study of the PVT Properties of Gas-Synthetic-Drilling-Fluid Mixtures Applied to Well Control.SPE116013, 2010 